\title{
Population structure of the bivalve Anomalocardia brasiliana, (Gmelin, 1791) in the semi-arid estuarine region of northeastern Brazil
}

\author{
Rodrigues, AML. , Borges-Azevedo, CM., Costa, RS. and Henry-Silva, GG. \\ Universidade Federal Rural do Semi-Arido, BR 110, km 47, Bairro Costa e Silva, Mossoró, RN, Brazil \\ *e-mail: allyssandramr@hotmail.com \\ Received June 29, 2012 - Accepted October 3, 2012 - Distributed November 29, 2013
}

(With 11 figures)

\begin{abstract}
For several decades, the bivalve mollusk Anomalocardia brasiliana has been extracted in estuarine areas in the semi-arid region of northeastern Brazil. However, information on both dynamics and abundance of their populations are missing. In this context, the present study, therefore, investigated several aspects of the population structure of $A$. brasiliana on beaches near the estuary of the Apodi River in Northeast Brazil. The aims were to determine the population density of $A$. brasiliana during different times of the year, to estimate population parameters, and to relate species density and distribution to the abiotic characteristics of the region. Sampling was performed from March/2007 and May/2008, we collected samples of sediments and mollusks along $180 \mathrm{~m}$ transects in the intertidal area on the beaches Barra and Pernambuquinho, Grossos - RN. At each sampling site, samples of sediments and mollusks were collected in the intertidal area along $180 \mathrm{~m}$ transects. The highest and lowest average densities on Pernambuquinho beach were 1148 (April/2007), and 100 individuals.m ${ }^{-2}$ (May/2008), respectively. On Barra beach, the highest and lowest densities were 1813 (April/2007) and 951 individuals. $\mathrm{m}^{-2}$, (November/2007), respectively. The densities of $A$. brasiliana on both beaches were significantly different only in the months of January, April and May/2008. Length of the individuals ranged from 1 to $28 \mathrm{~mm}$, with most individuals measuring between 22 and $24 \mathrm{~mm}$. Length growth rate parameters for A. brasiliana were $\mathrm{L} \infty=28.68 \mathrm{~mm}$ and $\mathrm{k}=0.61$ year $^{-1}$ on Barra beach, and $\mathrm{L} \infty=29.87 \mathrm{~mm}$ and $\mathrm{k}=0.48$ year $^{-1}$ on Pernambuquinho beach. The growth rate curves for $A$. brasiliana suggest the presence of three well defined cohorts, thus pointing to a continuous reproduction cycle with peak recruitment between October/2007 and March/2008. $A$. brasiliana density decreased predominantly during the heavy rains of 2008, probably due to an accumulation of sediments and decreasing salinity. This disturbance probably affected population of this species in the region.
\end{abstract}

Keywords: bivalve mollusk, growth, recruitment, estuary, tropical.

\section{Estrutura populacional do bivalve Anomalocardia brasiliana, (Gmelin, 1791) em região estuarina do semi-árido do nordeste brasileiro}

\begin{abstract}
Resumo
O molusco bivalve Anomalocardia brasiliana há décadas vem sendo coletado em região estuarina do semi-árido do nordeste Brasileiro. No entanto, são escassas as informações sobre a dinâmica e abundância de suas populações na região. Neste contexto, o presente trabalho objetivou estudar aspectos da estrutura populacional de $A$. brasiliana em praias localizadas próximas à região de estuário do rio Apodi/Mossoró - RN no intuito de verificar a densidade populacional de $A$. brasiliana durante as diferentes épocas do ano; estimar os parâmetros populacionais e relacionar as características abióticas de região com a distribuição e densidade desta espécie. As coletas foram realizadas no período de março/2007 a maio/2008 nas praias de Barra e Pernambuquinho no município de Grossos - RN. Em cada ponto foram realizados transcectos de 180 metros na região de entremarés e coletadas amostras de sedimento e de moluscos. O maior valor médio de densidade na praia de Pernambuquinho foi de 1148 indivíduos $/ \mathrm{m}^{2}$, no mês de abril $/ 07$ e o menor foi em maio/08 (100 indivíduos $/ \mathrm{m}^{2}$ ). Na praia de Barra o maior valor foi de 1813 indivíduos $/ \mathrm{m}^{2}$, no mês de abril/08 e o menor foi em novembro/07 com 951 indivíduos $/ \mathrm{m}^{2}$. Os comprimentos variaram de 1 a $28 \mathrm{~mm}$, sendo mais frequentes indivíduos com comprimentos entre 22 a $24 \mathrm{~mm}$. Foram constatadas diferenças significativas entre as densidades de $A$. brasiliana em ambas as praias, apenas nos meses de janeiro, abril e maio de 2008. Os parâmetros que descrevem o crescimento em comprimento de $A$. brasiliana na praia de Barra foram: $\mathrm{L} \infty=28,68 \mathrm{~mm} \mathrm{e} \mathrm{k}=0,61 \mathrm{ano}^{-1}$, enquanto que para a praia de Pernambuquinho foram: $\mathrm{L} \infty=29,87 \mathrm{~mm}$ e k $=0,48$ ano $^{-1}$. As curvas de crescimento de $A$.
\end{abstract}


brasiliana sugerem a presença de três coortes bem definidas, indicando uma reprodução contínua com picos de recrutamento ocorrerendo entre os meses de outubro/07 a março/08. Pode-se verificar uma diminuição da densidade de A. brasiliana, especialmente no período de chuvas intensas do ano de 2008 , o que provavelmente esteve associado ao aporte de sedimentos e a diminuição da salinidade. Esta perturbação provavelmente afetou as populações desta espécie na região.

Palavras-chave: molusco bivalve, crescimento, recrutamento, estuário, tropical.

\section{Introduction}

Estuaries are transitional environments between river and marine ecosystems. They are dynamic systems due to factors like hydrological characteristics (regime of river flows, tidal movement, and wind) (Edgar et al., 1999; Perillo, 1996). Estuaries present a high diversity of animal species, especially invertebrates, thus forming the basis of many artisanal fisheries in coastal communities (Barletta and Costa, 2009; Rodrigues, 2009; GuebertBartholo et al., 2011).

Along the Brazilian coast, several local communities exploit the natural stocks of shellfish (Gil et al., 2007). Outstanding among these is the species Anomalocardia brasiliana because it is part of the diet of the fishermen as well as an important source of income. However, unregulated exploitation of this mollusk is compromising its stocks in several parts of the Brazilian Northeast, such as Pernambuco and Rio Grande do Norte (Oliveira, 2010; Rodrigues, 2009).

A. brasiliana, in Brazil known by several common names such as "berbigão", "vôngole", "maçunin", "chumbinho", and "búzio", is distributed from the West Indies to Uruguay, and occurs throughout the Brazilian coast (Boehs et al., 2008; Rios, 1994). It inhabits preferentially areas with calm waters and sandy-silt sediment, where it occurs predominantly in the first $10 \mathrm{~cm}$ of the sediment column of the shallow subtidal, intertidal, or mangrove areas (Gofferjé, 1950; Narchi, 1974; Schaeffer-Novelli, 1980; Monti et al., 1991; Boehs et al., 2008; Rodrigues, 2009). This has important nutritional seafood, characterised as an expressive source of protein and minerals and low calorie value (Pedrosa and Cozzolino, 2001). The population of $A$. brasiliana may be dominant over other benthic species, forming banks with high density of individuals (Schaeffer-Novelli, 1980). Yet, in addition to their dominant environment, A. brasiliana is able to form natural banks in habitats with sandy-muddy soil of back coves, bays and estuaries (Pezzuto and Echternacht, 1999; Rios, 1994; Poli et al., 2004), which can be classified as eurihaline and eurythermal (Leonel et al., 1983). Furthermore, this mollusk species is capable of surviving prolonged periods of anoxia and displays rapid growth (Hiroki, 1971; 1977; Monti et al., 1991; Pezzuto and Echternacht, 1999).

Studies on the population structures of economically important mollusks in Brazil are scarce thus hindering severely the basic survey work necessary to provide advice concerning their rational exploitation. Studies on the biology and ecology of bivalve mollusks are fundamental to establish management programs that aim at maintain- ing their natural populations, thus contributing to the development of sustainable extraction and mariculture (Moreira, 2007). Hence, the determination of the potential for sustainable exploitation of fishing resources needs to be based on population assessment and studies of population dynamics (Deffeo, 1998; Maliao et al., 2004; Deffeo and Castilla, 2005).

Given the importance of understanding both the ecology and the dynamics of commercially important mollusk species for establishing rational management, this study aimed at evaluating the population structure of $A$. brasiliana in an estuary in the semi-arid region of northeastern Brazil, and investigating possible relations to the abiotic characteristics of the study area.

\section{Material and Methods}

The study was performed at the Costa Branca region, the only place in Brazil where the savannah and the sea have a common boundary. According to the KöppenGeiger classification, this region is in the category of Bsw'h' or hot and semiarid climate.

Sampling occurred during 15 months, from March/2007 to May/2008, on the beaches Barra and Pernambuquinho near the estuary of the Apodi-Mossoró River, in Grossos county, RN (04 55'50"' S; $\left.37^{\circ} 09^{\prime} 30^{\prime \prime} \mathrm{W}\right)$ (Figure 1). At each sampling site (Barra and Pernambuquinho), we established a $180 \mathrm{~m}$ long transect towards the sea with one sampling point every $20 \mathrm{~m}$ (total of 10 sampling points). All sampling points were georeferenced by GPS (Global Positioning System), using projection UTM (Universal Transverse Mercator) Zone $24 \mathrm{~S}$.

Due to the fact that Anomalocardia brasiliana occurs predominantly in the first $10 \mathrm{~cm}$ of the sediment column (Silva and Silveira, 1992; Narchi, 1972; Schaeffer-Novelli, 1980), we used a circular collector with an area of $0.0192 \mathrm{~m}^{2}$ buried approximately $10 \mathrm{~cm}$ into the substrate to collect the animals. The collected specimens were washed, and subsequently stored in labelled plastic vials and frozen for further analysis. The sediment was collected using a galvanised iron collector with a diameter of $5.6 \mathrm{~cm}$ and a length of $10 \mathrm{~cm}$. The collected material was analysed at the Laboratory of Limnology of the Brazilian Federal University at Mossoró-RN (Universidade Federal Rural do Semi-Árido, UFERSA). Shell length of all living individuals of $A$. brasiliana was determined using a $0.05 \mathrm{~mm}$ precision caliper. The sediment was collected using a galvanised iron collector with a diameter of $5.6 \mathrm{~cm}$ and a length of $10 \mathrm{~cm}$. For the analysis, the samples were oven-dried at $60^{\circ} \mathrm{C}$ until constant weight. Sub- 

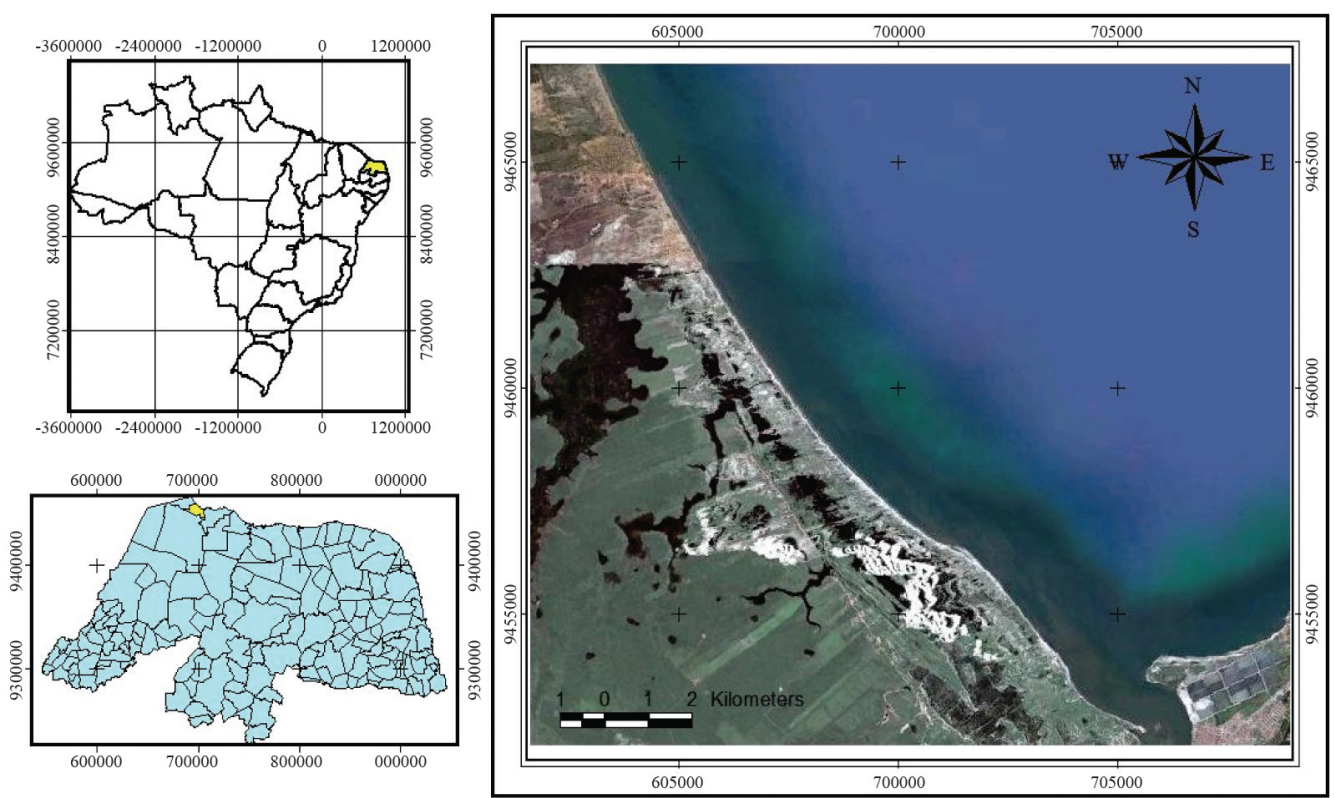

Figure 1 - Sampling sites of Anomalocardia brasiliana on Barra and Pernambuquinho beaches, Grossos, Rio Grande do Norte, northeastern Brazil.

sequently, particle size was determined using a series of six sieves with the following meshes: $2,1,0.5,0.25$, 0.125 and $0.053 \mathrm{~mm}$. After determining sediment weight in each sieve, sediment type was classified according to Shepard (1954) as: gravel, coarse and very coarse sand, medium sand, fine and very fine sand plus, silt and clay. Water temperature and salinity were determined using "Water Quality Checker", model U-10 (Horiba), and a manual optical refractometer, respectively. Rainfall data of the study region were supplied by the company "F. Souto Indústria, Comércio e Navegação S.A".

Non-parametric Kruskall-Wallis tests (followed by Dunn's test for multiple comparisons of non-parametric data from different size samples) and Mann-Whitney tests were used to evaluate potential differences in abundance of $A$. brasiliana over time (15 months) on each of the studied beaches, and between both beaches each month, respectively. The significance level was $\mathrm{p} \leq 0.05$.

The spatial distribution of $A$. brasiliana was verified for each month of collection through the index of Morisita (I $\delta$ ), with statistical significance verified by $\mathrm{F}$ test (Ludwig and Reynolds, 1988), and when $I \delta=1$, the distribution is random, when $I \delta>1$, the distribution is aggregated and when $I \delta<1$, the distribution is uniform.

$$
\mathrm{I} \delta=\mathrm{N} \frac{\sum \mathrm{x}^{2}-\sum \mathrm{x}}{\left(\sum \mathrm{x}\right)^{2}-\sum \mathrm{x}}
$$

where I $\delta=$ Index Morisita, $N=$ number of sample units, and $\Sigma \mathrm{x}=$ summation of individual units.

Growth rates were estimated from the length frequency of the shells, using the software package FISAT
II (FAO/ICLARM Stock Assessment Tools) (Gayanillo et al., 1997). Growth rate parameters and cohort identification were estimated by the VonBertalanfy inverted equations and the Bhattacharya (1967) method, respectively. Based on the monthly frequency distributions of standard length, the following growth parameters were determined by the Von Bertalanffy (1939) inverted equation (VBGF):

$$
\mathrm{t}(\mathrm{L})=\mathrm{t}_{0}-1 / \mathrm{k} * \ln (1-\mathrm{L} / \mathrm{L} \infty)
$$

where $t(L)=$ age, $t_{0}=$ parameter related to mollusks birth length, $\mathrm{k}=$ growth coefficient (year ${ }^{-1}$ ), $\mathrm{ln}=$ logarithm, $\mathrm{L}=$ length, and $\mathrm{L} \infty=$ asymptotic standard length $(\mathrm{mm})$. From this, the length growth can be calculated as follows:

$$
\mathrm{L}_{\mathrm{t}}=\mathrm{L} \infty\left[1-\exp \left(\begin{array}{r}
-\mathrm{k}(\mathrm{t}-\mathrm{t}) \\
0
\end{array}\right)\right]
$$

\section{Results}

Between March and June/2007, minimum and maximum rainfall rates were $79 \mathrm{~mm}$ (June/2007) and $147.5 \mathrm{~mm}$ (April/2007), respectively. There was practically no rainfall in the remainder of 2007 . In January/2008, $5 \mathrm{~mm}$ of rainfall were recorded. However, no data were available for February/2008. In March, April, and May/2008, the recorded rainfall rates were 378.5, 197.5 and $162 \mathrm{~mm}$, respectively (Figure 2).

Water temperatures showed a small difference between the two sampling sites. At Barra beach, water temperatures varied between $28.4^{\circ} \mathrm{C}$ (September/2007) and $35.2{ }^{\circ} \mathrm{C}$ (December /2007), and had an average of $32.7^{\circ} \mathrm{C}$. At Pernambuquinho beach, the lowest and highest water temperatures were $28.3^{\circ} \mathrm{C}$ (September/2007) 


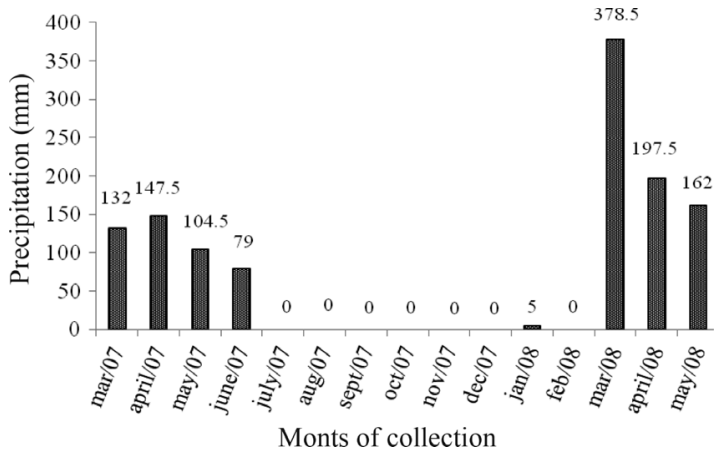

Figure 2 - Rainfall in the region of Grossos, Rio Grande do Norte, northeastern Brazil, between March 2007 and May 2008.

and $34.8^{\circ} \mathrm{C}(\mathrm{March} / 2008)$, respectively, with an average of $31.2^{\circ} \mathrm{C}$ (Figure 3 ).

At Pernambuquinho beach, salinity varied from the 47 (March/2008) to 15 (April and May/2008), with an av- erage of 37.6. At Barra beach, the highest and lowest salinities were 49 (December/2007), and 10 (May/2008), respectively, with an average of 41 (Figure 3 ).

Particle size analysis showed that the sediment at Barra beach had an average composition of $32 \%$ silt, clay and very fine sand, $24 \%$ fine sand, $5.8 \%$ medium sand, $14.6 \%$ coarse sand, and $23.6 \%$ gravel. The sediment was composed of $60 \%$ silt, clay, fine and very fine sand in March 2007. In April, May, and June/2007, the relative contribution for these size classes was $66 \%, 69 \%$, and $64 \%$, respectively. The sediment from Pernambuquinho beach had an average composition of $30.8 \%$ silt, clay and very fine sand, $41 \%$ fine sand, $5.5 \%$ medium sand, $10.9 \%$ coarse sand, and 11.8\% gravel. In March 2007, the sediment at this beach was composed of $66 \%$ silt, clay, fine and very fine sand in March/2007. In April, May, and June/2007, the proportion of these size classes was $81 \%$, $84 \%$, and $75 \%$, respectively (Figure 4). At Pernambuquinho beach, the average composition of the sediment was: silt, clay and very fine sand: $30.8 \%$; fine sand: $41 \%$; medium sand: $5.5 \%$; coarse sand: $10.9 \%$; gravel: $11.8 \%$.
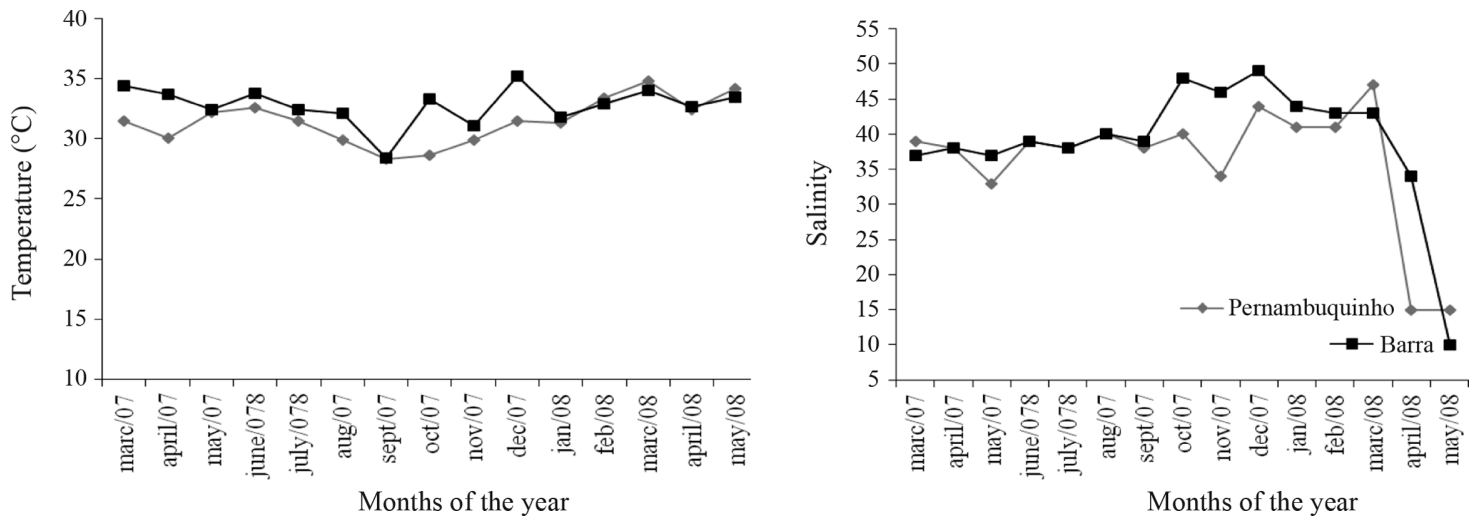

Figure 3 - Monthly water temperature $\left({ }^{\circ} \mathrm{C}\right)$ and salinity on the beaches Pernambuquinho (open symbols) and Barra (filled symbols), Rio Grande do Norte, Northeastern Brazil, between March 2007 and May 2008.
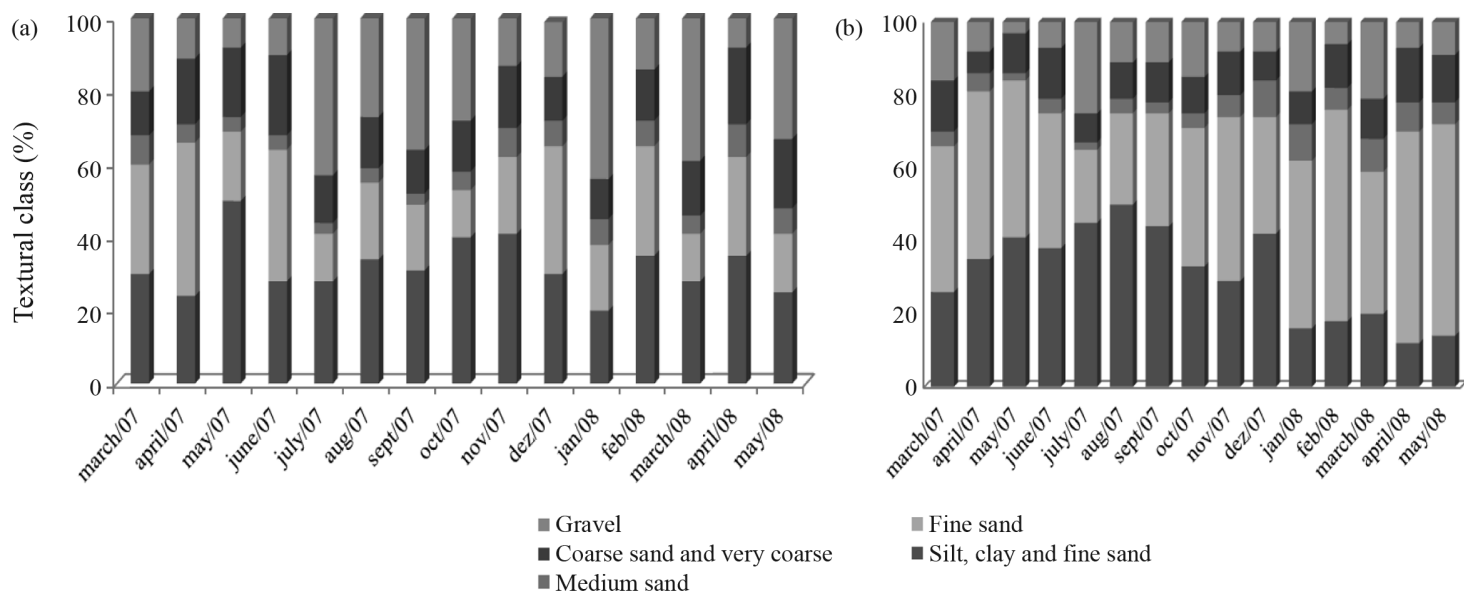

$$
\begin{aligned}
& \text { - Fine sand } \\
& \text { - Silt, clay and fine sand }
\end{aligned}
$$

Figure 4 - Particle size distribution for the sediment of Barra (a) and Pernambuquinho (b) beaches, Rio Grande do Norte, northeastern Brazil. 


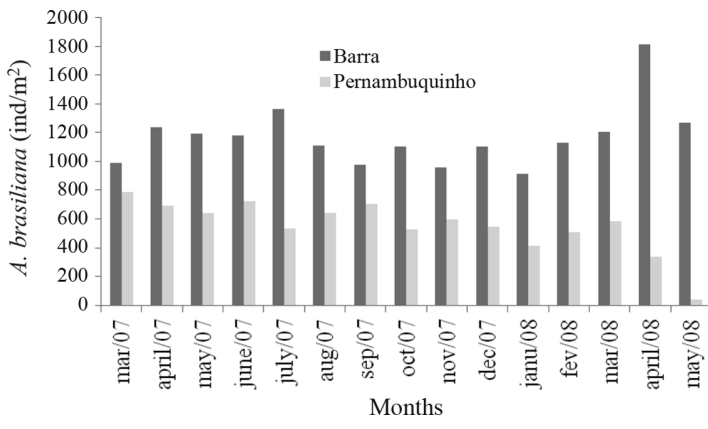

Figure 5 - A. brasiliana abundance mean values for the beaches of Barra and Pernambuquinho during the period between March/2007 and May/2008, Rio Grande do Norte, northeastern Brazil.

On Barra, particle size distribution was as follows: silt, clay and very fine sand: $32 \%$; fine sand: $24 \%$; medium sand: $5.73 \%$; coarse sand: $14.6 \%$; gravel: $23.6 \%$.

\subsection{A. brasiliana population structure}

In the study period (March/2007 to May/2008), the average population densities of $A$. brasiliana were 773 individuos. $\mathrm{m}^{-2}$ at Pernambuquinho beach, and 1215 at Barra beach Maximum and minimum densities were 1148 (April/2007) and 100 individuos.m ${ }^{-2}$ (May/2008) at

\section{Barra}
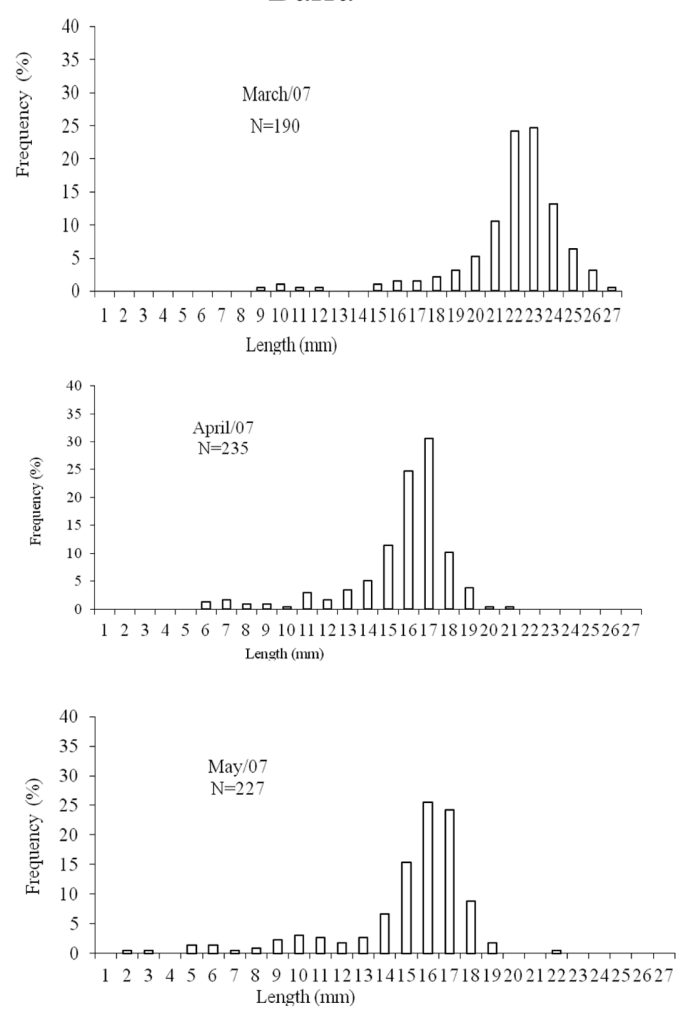

Pernambuquinho, and 1813 (April/2008) and 951 individuos. $\mathrm{m}^{-2}$ (November/2007) at Barra beach (Figure 5).

Animal length varied between 1 and $28 \mathrm{~mm}$ at both beaches. In March/2007 the majority of individuals measured between 22 and $24 \mathrm{~mm}$. In the last month of sampling (May/2008), the length of the collected $A$. brasiliana individuals ranged from 1 to $15 \mathrm{~mm}$. On Pernambuquinho beach, individuals measuring between 14 and $20 \mathrm{~mm}$ were most abundant during great parts of the study period (Figure 6).

We found no significant differences in the abundance of A. brasiliana on Barra beach (Kruskal-Wallis: $\mathrm{H}=14.7 ; \mathrm{p}=0.398$ ) during our study. On Pernambuquinho beach, the abundance of the mollusk was significantly lower in April and May 2008 compared to the other months of sampling (Kruskal-Wallis: $\mathrm{H}=24.2$; $\mathrm{p}=0.042$ ) (Figure 7).

Comparing the density of $A$. brasiliana between the two sampling sites, we found a significantly lower abundance of the mollusk at Pernambuquinho beach compared to Barra beach in January, April and May/2008 (Figure 8).

Analysing the abundance of $A$. brasiliana between points along the transect, we found that at Barra beach there was a clear pattern of increase or decrease in abundance from $1(0 \mathrm{~m})$ to point $10(180 \mathrm{~m})$ (Figure 9). On

\section{Pernambuquinho}
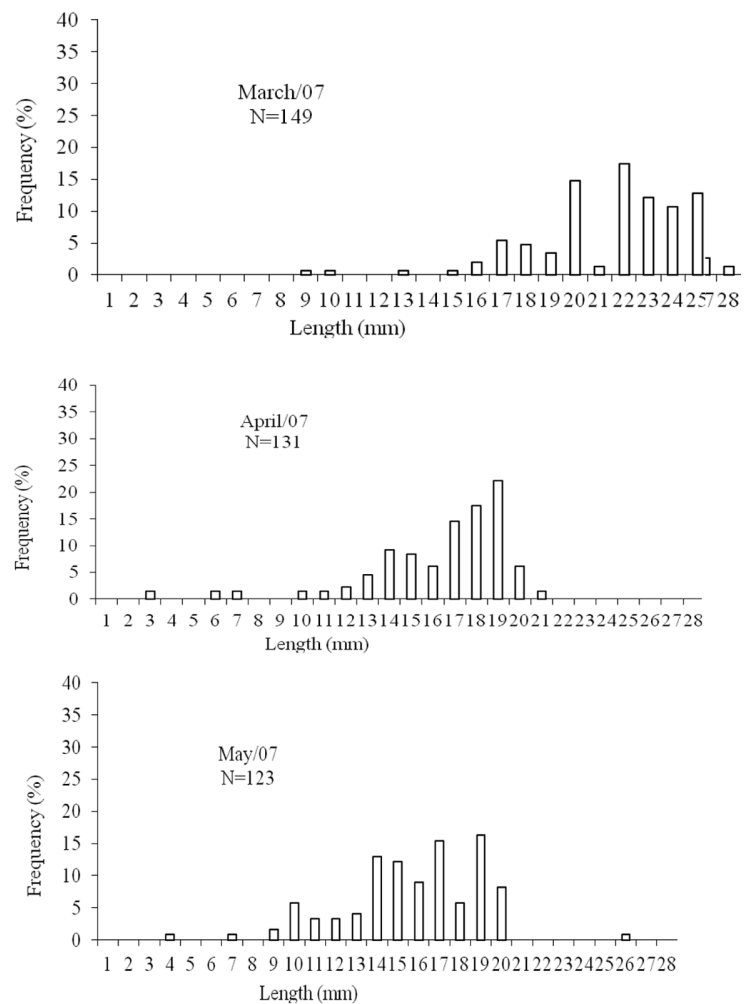

Figure 6 - Length frequency $(\mathrm{mm})$ of Anomalocardia brasiliana individuals sampled on the beaches Barra and Pernambuquinho between March/2007 and May/2008. 
Rodrigues, AML. et al.
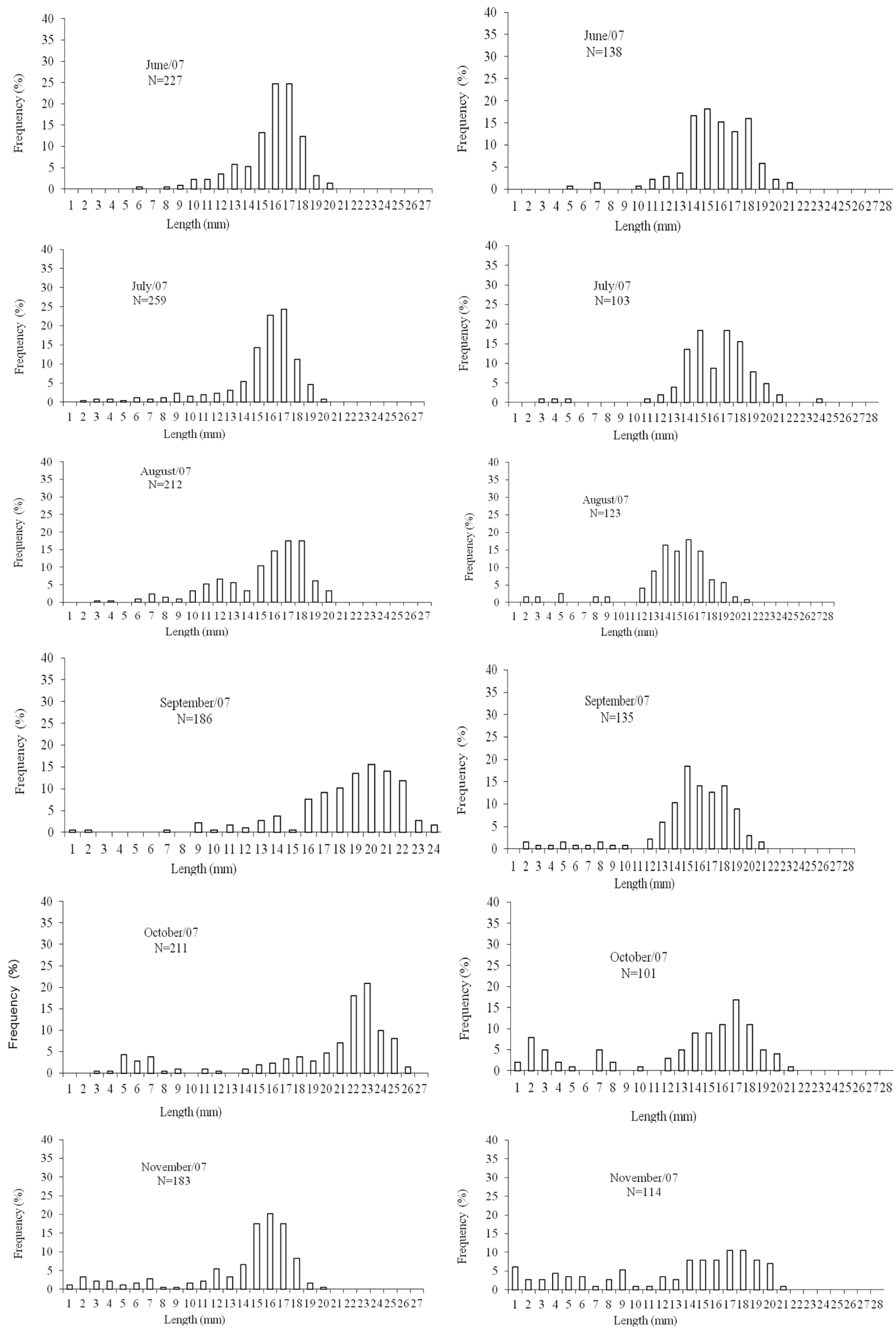

Figure 6 - (cont.) 

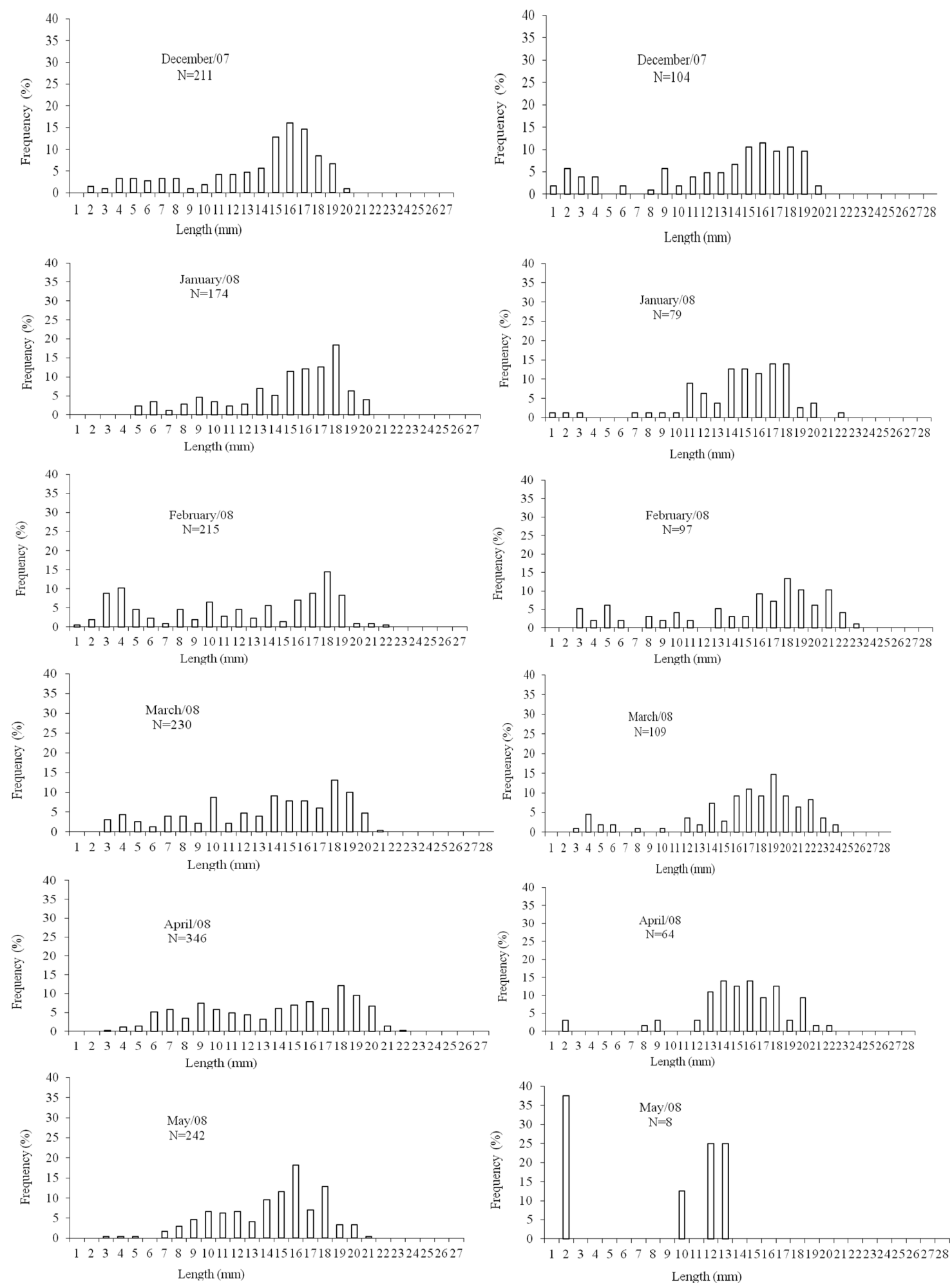

Figure 6 - (cont.) 


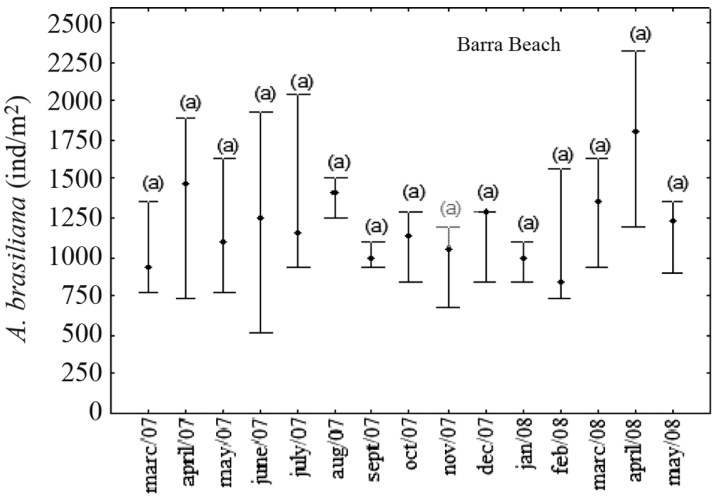

Months

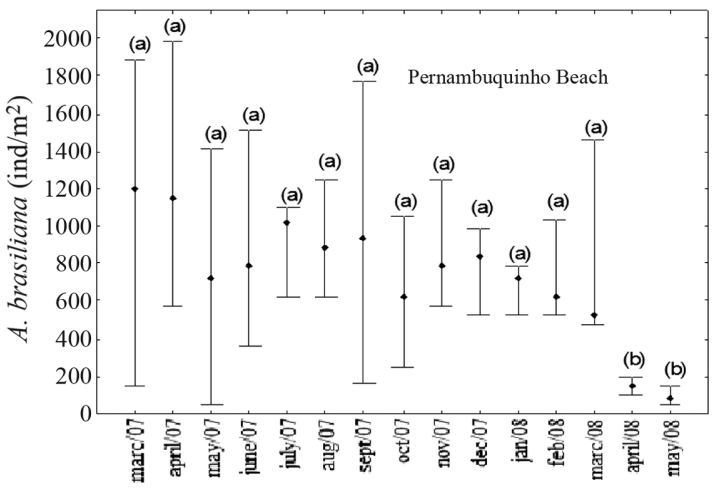

Months

Figure 7 - Abundance of $A$. brasiliana on the beaches Barra and Pernambuquinho during the period between March/2007 and May/2008, Rio Grande do Norte, Northeastern Brazil. Given are mean values of samples per site and month, and lower (25\%) and higher (75\%) quartiles. Different letters indicate significantly different samples $(\mathrm{p} \leq 0.05)$.

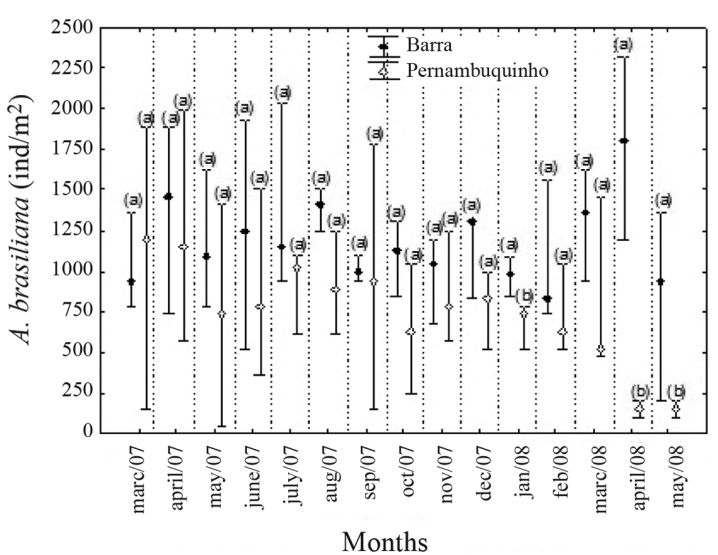

Figure 8 - Abundance of A. brasiliana on the beaches Barra (filled symbols) and Pernambuquinho (open symbols) during the period between March/2007 and May/2008, Rio Grande do Norte, Northeastern Brazil. Given are mean values \pm standard deviation of samples per site and month. Different letters mean significant differences between sampling sites (Mann-Whitney test: $\mathrm{p} \leq 0.05$ ). the other hand, at collection points on Pernambuquinho beach, it was found that the first points $1(0 \mathrm{~m})$ to $4(60$ $\mathrm{m})$ of the transect showed no individuals in most sampling months (Figure 10). The greater A. brasiliana abundance started from the point of transect $5(80 \mathrm{~m})$ in almost every month. The last point of the transect $(180 \mathrm{~m})$ showed individuals in all sampling months. In May/08, abundance occurred in smaller quantities and only in some parts of the transect. Regarding density variation in most months, the lowest average values of A. brasiliana were observed in the points near the beach (between 0 and $60 \mathrm{~m}$ ). By applying the Morisita Index, it was found that the values varied between 1.0 and 1.5, revealing the aggregative characteristic of this species (Figures 9 and 10).

The parameters $\mathrm{L} \infty$ and $\mathrm{k}$ calculated to describe the length growth rate of $A$. brasiliana were $28.68 \mathrm{~mm}$ and 0.61 year $^{-1}$ (Barra), and $29.87 \mathrm{~mm}$ and 0.48 year $^{-1}$ (Pernambuquinho), respectively. The curves describing length growth rates of $A$. brasiliana suggest the presence of three well defined cohorts on both beaches (Figure 11).

\section{Barra}
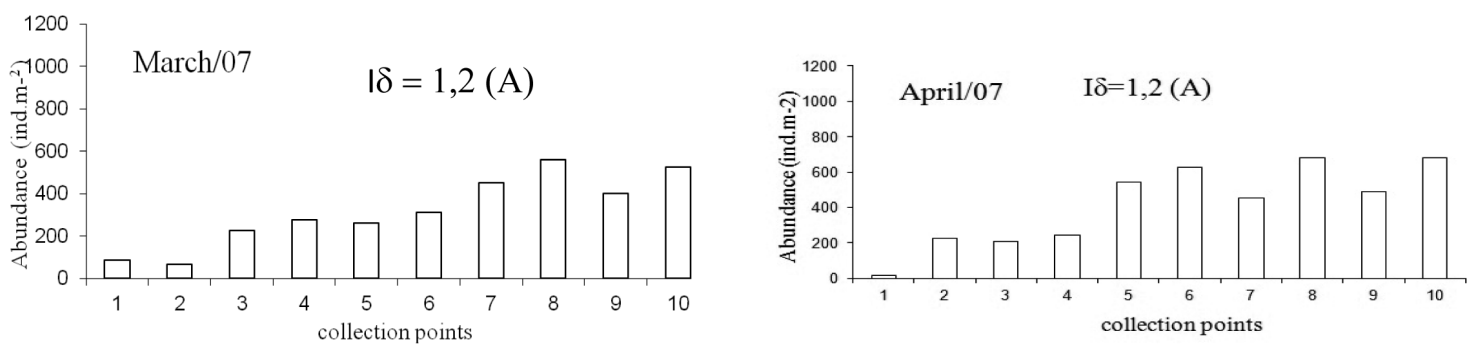

Figure 9 - Histograms showing abundance (individuals. $\mathrm{m}^{-2}$ ) of Anomalocardia brasiliana beach Barra between 10 collection points in the transects months march/07 to may/08. I $\delta=$ Morisita Index $(A)=$ Clustered distribution pattern. 

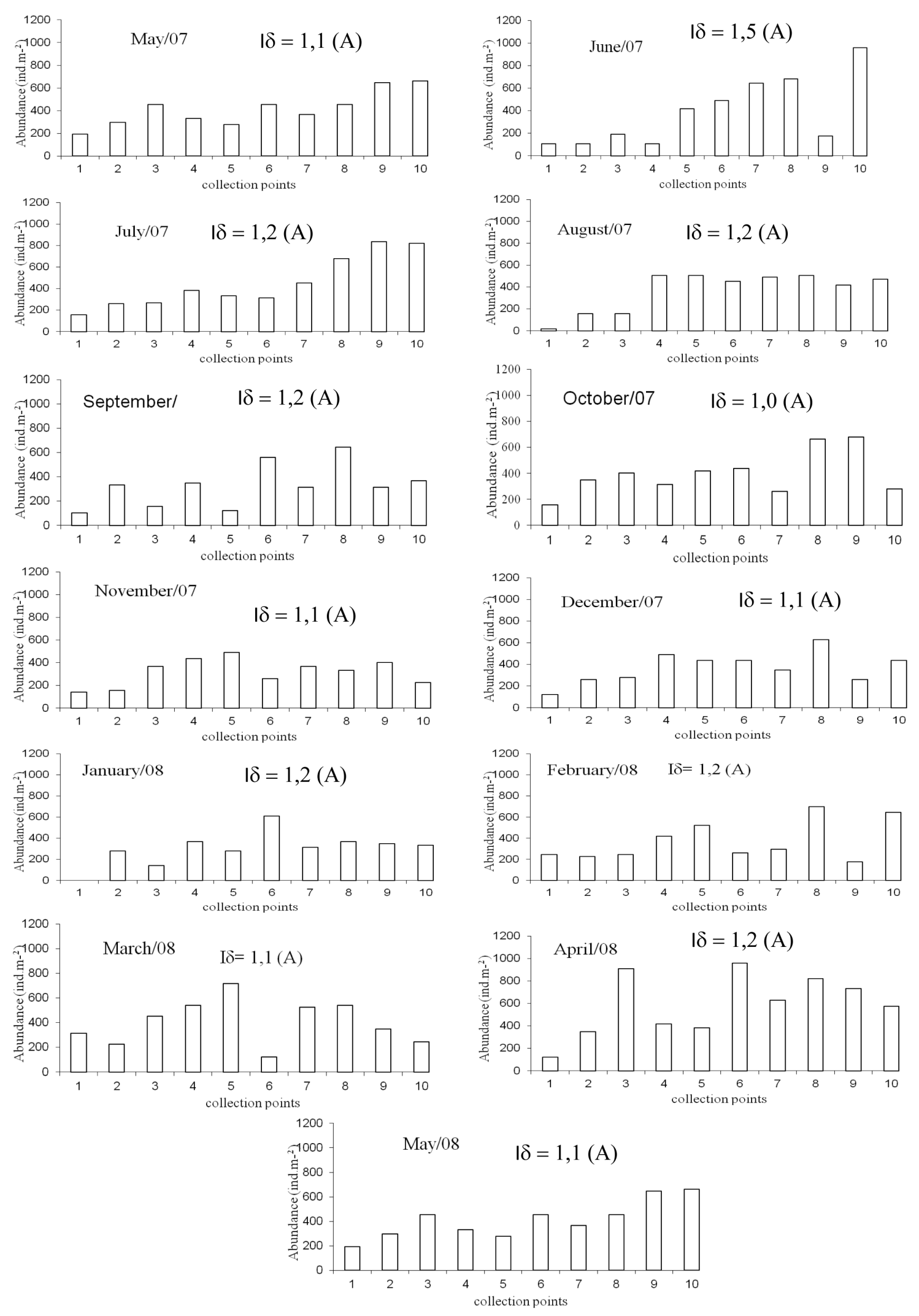

Figure 9 - (cont.) 
The inverted Von Bertalanfy equation gives an esti- $\quad$ beaches Barra and Pernambuquinho, assuming $\mathrm{t}_{0}=0$ (Tamate of length-age structure for A. brasiliana on the ble 1).

\section{Pernambuquinho}
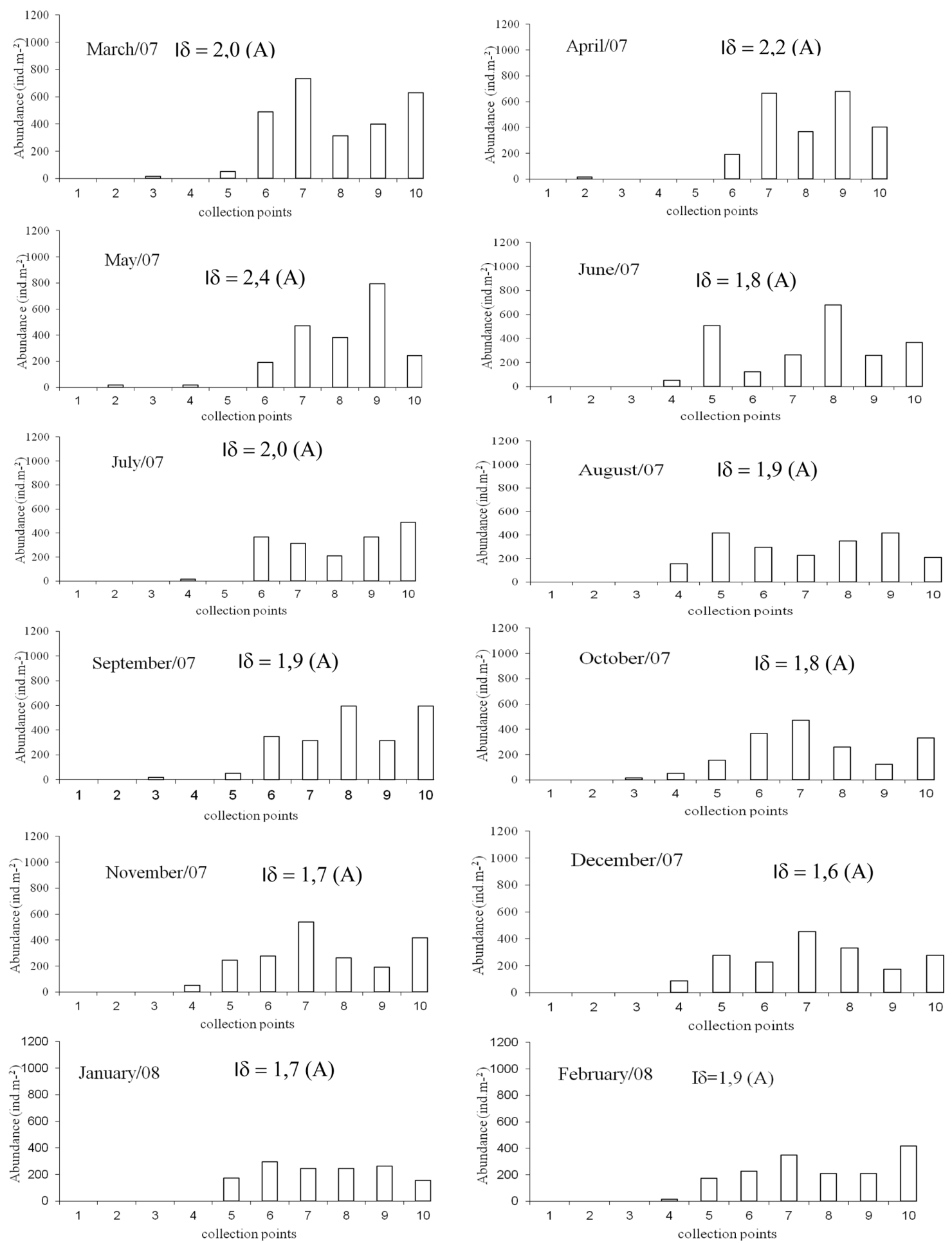

Figure 10 - Histograms showing abundance (individuals.m-2) of Anomalocardia brasiliana at Pernambuquinho beach between 10 collection points in the transects months march $/ 07$ to may $/ 08$. I $\delta=$ Morisita Index $(\mathrm{A})=$ Clustered distribution pattern. 


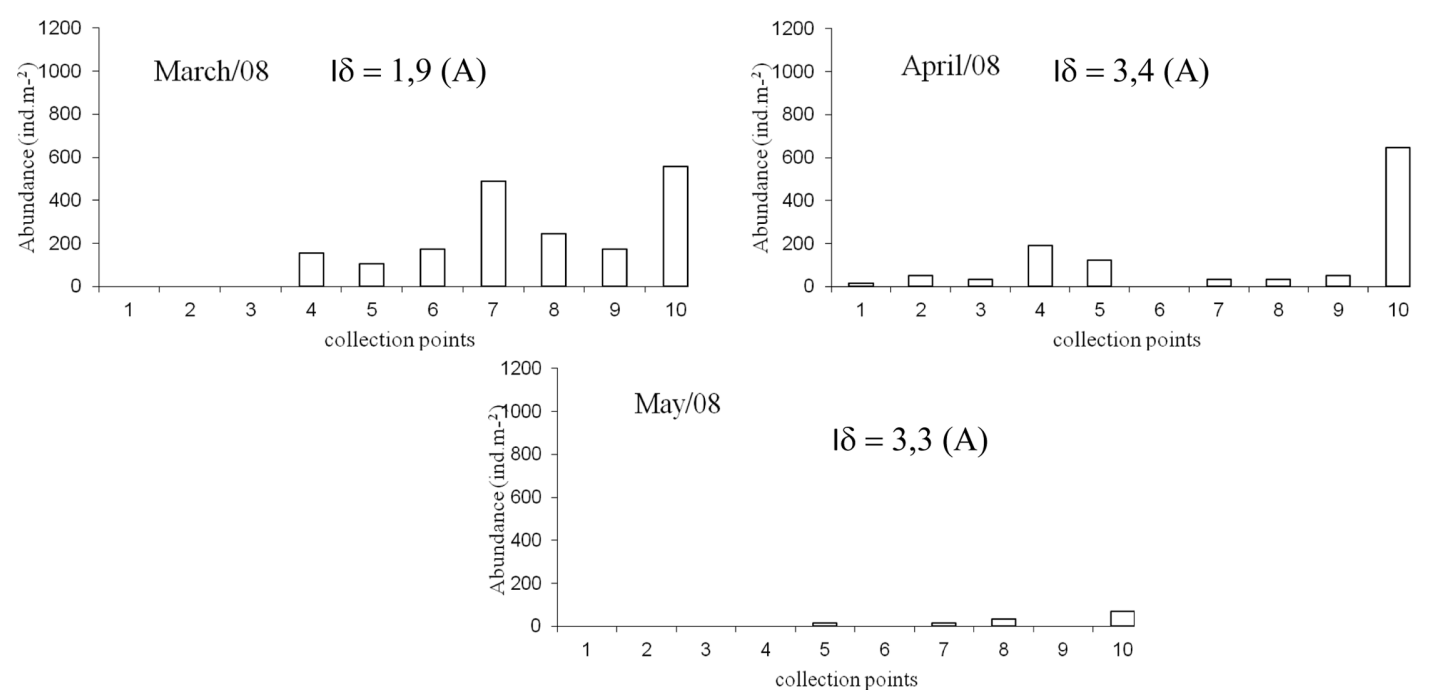

Figure 10 - (cont.)
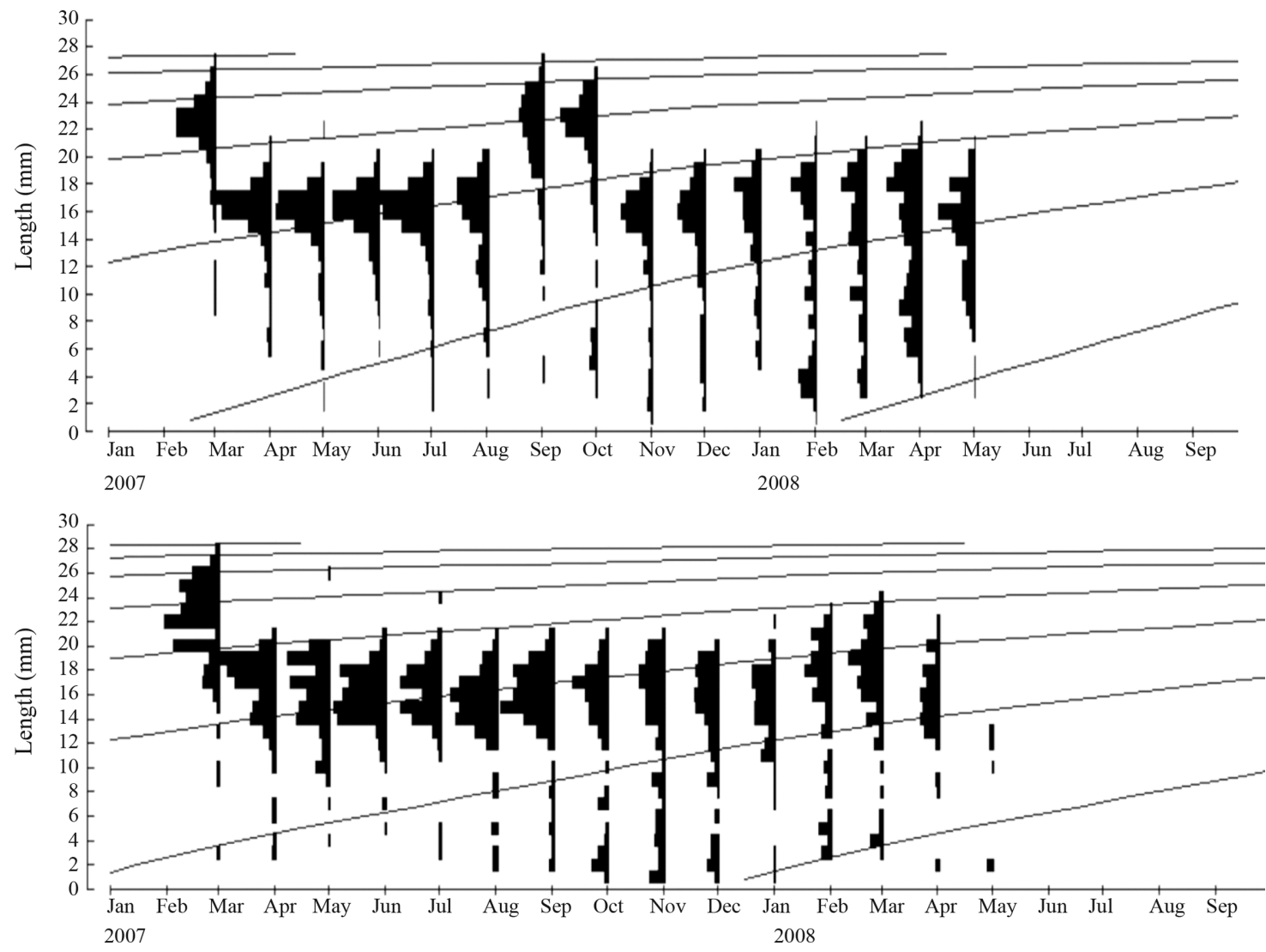

Figure 11 - Length frequency distribution and estimated growth rate curves for $A$. brasiliana at the beaches Barra and Pernambuquinho, Rio Grande do Norte, northeastern Brazil, between March/2007 and May/2008.

\section{Discussion}

The two beaches studied presented similar water temperatures with little variation between beaches and seasons. This was certainly due to the geographic proximity of both study sites and the climatic characteristics of the region, where temperatures change little in the course of the year. Other studies on populations of $A$. 
Table 1 - Mean age-length structure ( $\mathrm{mm})$ of $A$. brasiliana determined from the individuals collected on Pernambuquinho and Barra beaches, Rio Grande do Norte, Northeastern Brazil, between March/2007 and May/2008.

\begin{tabular}{|c|c|c|}
\hline $\begin{array}{l}\text { Mean length } \\
(\mathrm{mm})\end{array}$ & $\begin{array}{c}\text { Relative age } \\
\text { (years) } \\
\text { Pernambuquinho }\end{array}$ & $\begin{array}{l}\text { Relative age } \\
\text { (years) Barra }\end{array}$ \\
\hline 1 & 0.074 & 0.058 \\
\hline 2 & 0.144 & 0.118 \\
\hline 3 & 0.220 & 0.181 \\
\hline 4 & 0.299 & 0.246 \\
\hline 5 & 0.381 & 0.314 \\
\hline 6 & 0.467 & 0.384 \\
\hline 7 & 0.556 & 0.458 \\
\hline 8 & 0.649 & 0.536 \\
\hline 9 & 0.746 & 0.617 \\
\hline 10 & 0.849 & 0.702 \\
\hline 11 & 0.956 & 0.793 \\
\hline 12 & 1.070 & 0.888 \\
\hline 13 & 1.190 & 0.989 \\
\hline 14 & 1.317 & 1.097 \\
\hline 15 & 1.453 & 1.213 \\
\hline 16 & 1.598 & 1.337 \\
\hline 17 & 1.754 & 1.472 \\
\hline 18 & 1.922 & 1.619 \\
\hline 19 & 2.105 & 1.780 \\
\hline 20 & 2.306 & 1.959 \\
\hline 21 & 2.529 & 2.159 \\
\hline 22 & 2.778 & 2.388 \\
\hline 23 & 3.061 & 2.654 \\
\hline 24 & 3.389 & 2.971 \\
\hline
\end{tabular}

brasiliana indicated that the population and occurrence of these bivalves is not influenced by temperature (study site Ceara: Barreira and Araújo, 2005; Paraiba: Grotta and Lunetta, 1980, 1982; São Paulo: Schaeffer-Novelli, 1980).

The maximum salinity values registered in December/2007 and March/2008 were probably due to the diminished influx rate of the Apodi River in the dry season, and to the release of salt washing water originating from salt marshes in the estuarine region. After the onset of the rains in March/2008, salinity decreased on both beaches, first on Pernambuquinho beach in April/2008, followed by a decrease on Barra beach in May/2008. This temporal delay in decrease in salinity between Pernambuquinho and Barra probably occurred because Pernambuquinho is more susceptible to receiving water directly from the Apodi River compared to Barra beach, which is physically more protected.
After the onset of the rains, the mean abundance of $A$. brasiliana decreased on both beaches. This decrease in mollusk population was probably a consequence of the decreasing salinity, which putatively induces mortality of the individuals. Borges-Azevedo et al. (1990), studying the bivalve Donax striatus on beaches near the estuary of the Apodi River, observed that intense rainfalls, when large amounts of fresh water are washed out to the beach, prevented the settlement of young individuals and caused adult mortality. Leonel et al. (1983) demonstrated that $A$. brasiliana survives salinity fluctuations of between 17 and 42 , with an optimum value of approximately 22 . In our study, salinity ranged from 10 to 48 . Mean mollusk density decreased only on Pernambuquinho beach when salinity values were below 15 . It is likely that $A$. brasiliana migrated from Pernambuquinho to Barra in April and May/2008, since salinity and population density decreased on Pernambuquinho, whereas density increased on Barra.

Particle size analysis revealed a predominance of silt, clay, fine and very fine sand at both study sites. The presence of these textural classes was related to the occurrence of $A$. brasiliana, especially at Pernambuquinho beach. Probably this species preferably inhabits sandyloam substrates alternating with fine sand at certain levels. In accordance with our findings, Boehs et al. (2008) reported a predominance of very fine and fine sand in two tidal shallows of the Bay of Paranaguá-PR inhabited by A. brasiliana. Similarly, Beasley et al. (2005), studying the diversity and abundance of mollusks in coastal habitats of Pará, also reported the occurrence of $A$. brasiliana in places with sand-clay sediments.

On Barra beach, the abundance of $A$. brasiliana was constant along the entire transect, which was probably due to the constant textural pattern of the beach, where we observed silt, clay, sand and gravel from point 1 to point 10 of the transect. On Pernambuquinho beach, by contrast, A. brasiliana abundance was low between transect points 1 and 4, probably due to the dominance of fine sand. At the remaining transect points, where fine sand and silt-clay were predominant, A. brasiliana abundance increased, which corroborates the idea that the mollusk prefers this type of sediment. Furthermore, on Pernambuquinho beach, the highest abundance of $A$. brasiliana was registered at points where shells (gravel) were most abundant, which indicates death and constant fixation of the species at these points.

Despite its close proximity to both beaches, the impact of the Apodi River was probably higher on $A$. brasiliana population of Pernambuquinho, thus the decreasing density during April and May, 2008. During these months, rainfall increased and salinity decreased. Therefore, intense rainfalls and the consequent salinity decrease may be considered a disturbance that dramatically reduced the population of $A$. brasiliana during this period. These disturbances may change density, population dynamics and the abiotic characteristics of the habitat (Pimm, 1984; Pickett and White, 1985; Neubert and Caswell, 1997). The rainfall between March and 
May/2008 was above the average expected for this time of the year not only in the estuarine region, but also throughout the entire basin of the Apodi River (EMPARN, 2009). In the rainy season of 2007 (March to May), when rainfall was within its expected average, salinity did not decrease and, consequently, the population of $A$. brasiliana was not considerably lower compared to the dry season.

The results showed minimal variations in the transects. The spatial pattern observed for A. brasiliana in the region was added. Similar pattern was observed for bivalve Mesodesma mactroides in the sandy beaches of Rio Grande do Sul (Bergonci and Thomé, 2008). The aggregate distribution can be an important strategy for mollusk species that inhabit sandy beaches and estuarine regions, as is the case with $A$. brasiliana. Several factors may contribute to this aggregative pattern of mollusks such as $A$. brasiliana, the ease of finding partners for mating and food, protection from predators, as well as an evolutionary strategy to resist desiccation (Martell et al., 2002; Morton et al., 2002). In general, the aggregate distribution tends to occur when the organisms find conditions favourable to their survival and reproduction (Ricklefs, 2010).

Although our results demonstrated that the recruitment of $A$. brasiliana is continuous throughout the year, we registered recruitment peaks on Pernambuquinho beach between October/2007 and December/2007, and in February and March/2008. The peaks on Barra beach occurred between October/2007 and March/2008. The increase of young individuals on both beaches occurred shortly after the rainy season, which in 2007 lasted until June in the region of our study. Similar to our study, Boehs et al. (2008) observed continuous recruitment in Paranaguá bay, PR. In that study, however, recruitment was more pronounced during fall (March to May), as well as in winter and spring (June to October). Narchi (1976), studying the reproduction cycle of $A$. brasiliana in Santos Bay, SP, also reported a continuous cycle for this species. This author described two main spawning periods, one from August to November and another from February to April, and a period of low spawning during the winter months.

Importantly, we observed that simultaneously to the increase in density of $A$. brasiliana juveniles, the population of larger sized individuals decreased. This may indicate a self-limitation imposed by the older classes of the population, which, when present in high densities, may reduce both space and food available for younger animals. Monti et al. (1991) suggested that the population size of $A$. brasiliana is predominantly controlled by high population densities and strong intraspecific competition. Boehs et al. (2008) reported that the recruitment success of $A$. brasiliana depends of the reduction of the adult stock, a fact also observed for other bivalve species such as Lucina pectinata (Gmelin), Tagelus plebeius (Lightfoot) and Tagelus divisus (Spengler) (Boehs et al., 2004).
The maximum length of $A$. brasiliana measured in our study was lower than that found by other authors for other regions of Brazil. Soares et al. (1982) reported 39 $\mathrm{mm}$ long individuals in the region of Ilha do Cardoso, SP. For comparison, the longest mollusk found in our study measured $28 \mathrm{~mm}$. This absence of larger animals is probably a consequence of the extraction of individuals longer than $18 \mathrm{~mm}$ by shellfish collectors that in the region of our study.

During the study period, we identified three cohorts at both sampling sites. The occurrence of several cohorts points to the fact that $A$. brasiliana reproduces continuously in this region. The values of the parameters $\mathrm{L} \infty$ and $\mathrm{k}$, used to estimate length growth rate of A. brasiliana, were $28.68 \mathrm{~mm}^{2}$ and 0.61 year $^{-1}$ (Barra), and $29.87 \mathrm{~mm}$ and 0.48 year $^{-1}$ (Pernambuquinho), respectively. RochaBarreira et al. (2002), studying the population structure of Donax striatus (Mollusca: Donacidae), reported $\mathrm{L} \infty=25.10 \mathrm{~mm}$ and $\mathrm{k}=1.16$ year $^{-1}$, while size ranged from 0.7 to $17.7 \mathrm{~mm}$.

It can be concluded that the decrease of $A$. brasiliana abundance observed during the rainy period in 2008, was probably associated with the accumulation of sediments and marked salinity decrease. The aggregated distribution pattern observed for $A$. brasiliana may be an important adaptive strategy for the species of mollusks that inhabit sandy beaches and estuarine regions. It was also found that A. brasiliana reproduces continuously on the beaches of the estuary, with recruitment peaks between October/2007 and March/2008, and spawning predominantly happening soon after the rain period, which tends to extend to the month of June. The results of this study are likely to assist in future $A$. brasiliana conservation programs on the shore of Rio Grande do Norte.

\section{Acknowledgments}

We would like to thank the Conselho Nacional de Desenvolvimento Científico e Tecnológico (CNPQ), the non-governmental organizations World Fisheries Trust and Terra Viva, as well as Projeto Gente da Maré for their help and support. Our thanks also go to Michael Hrncir for linguistic revision of the text.

\section{References}

BARLETTA, M. and COSTA, MF., 2009. Living and nonliving resources exploitation in a tropical semi arid estuary. Journal of Coastal Research, vol. 56, p. 371-375.

BARREIRA, CAR. and ARAÚJO, MLR., 2005. Ciclo reprodutivo de Anomalocardia brasiliana (Gmelin, 1791) (Mollusca, Bivalvia, Veneridae) na Praia do Canto da Barra, Fortim, Ceará, Brasil. Boletim do Instituto de Pesca, vol. 31, no. 1, p. 9-20.

BEASLEY, CR., FERNANDES, CR., GOMMES, CP., BRITO, BA., SANTOS, SML. and TAGLIARO, CH., 2005. Molluscan diversity and abundance among coastal habitats of northern Brazil. Ecotropica, vol. 11, p. 9-20.

BERGONCI, PEA. and THOMÉ, JW., 2008. Vertical distribution, segregation by size and recruitment of the yellow clam Mesodesma mactroides Deshayes, 1854 (Mollusca, 
Bivalvia, Mesodesmatidae) in exposed sandy beaches of the Rio Grande do Sul state, Brazil. Brazilian Journal of Biology, vol. 68, p. 297-305.

BERTALANFFY, LA., 1939. Quantitative theory of organic growth. Human Biology, vol. 10, no. 2, p. 181-213.

BHATTACHARYA, CG., 1967. A simple method of resolution of a distribuition into Gaussian componentes. Biometrics, vol. 23, p. 115-135.

BOEHS, G. and MAGALHÃES, ARM., 2004. Simbiontes associados com Anomalocardia brasiliana (Gmelin) (Mollusca, Bivalvia, Veneridae) na Ilha de Santa Catarina e região continental adjacente, Santa Catarina, Brasil. Revista Brasileira Zoologia, vol. 21, no. 4, p. 865-869.

BOEHS, G., ABSHER, TM. and CRUZ-KALED, AC., 2008. Ecologia populacional de Anomalocardia brasiliana (Gmelin, 1791) (Bivalvia: Veneridae) na Baía de Paranaguá, Paraná, Brasil. Instituto Brasileiro de Pesca, vol. 34, no. 2 , p. $259-270$

BORGES-AZEVEDO, CMS., MOURA NETO, EL. and SILVA, JS., 1990. Densidade populacional de Donax striatus Linnaeus (1767) (Bivalvia: Donacidae) na praia de Tibau, Grossos, Rio Grande do Norte. Caatinga, vol. 7, p. 63-75.

DEFFEO, O., 1998. Testing hypotheses on recruitment, growth, and mortality in exploited bivalves: an experimental perspective. Canadian special publication of fisheries and aquatic sciences, vol. 125, p. 257-254.

DEFFEO, O. and CASTILLA, JC., 2005. More than one bag for the world fishery crisis and keys for co-management successes in selected artisanal Latin American shellfisheries. Reviews in Fish Biology and Fisheries, vol. 15, p. 265283.

EDGAR, GJ., BARRETT, NS. and LAST, PR., 1999. The distribution of macroinvertebrates and fishes in Tasmanian estuaries. Journal of Biogeography, vol. 26, p. 1169-1189.

Empresa de pesquisa agropecuária do Rio Grande do Norte EMPARN. Available from: www.emparn.rn.gov.br. Access in: 15 may 09 .

GAYANILLO JR., FC. and PAUL, YD., 1997. FAO-ICLARM Stock Assessment Tools (FISAT) Reference Manual. FAO Computerized Information Series (Fisheries), vol. 8, no. $2,249 \mathrm{p}$.

GIL, GM., TRONCOSO, JS. and THOMÉ, JW., 2007. Manual para manejo e otimização na exploração comercial de moluscos bivalves. Porto Alegre: Edição do Autor.

GOFFERJÉ, CN., 1950. Contribuição à zoogeografia da malacofauna do litoral do Estado do Paraná. Arquivos Museu Paraná, vol. 8 p. 221-281.

GUEBERT-BARTHOLO, FM., BARLETTA, M., COSTA, MF., LUCENA, LR. and SILVA, CP., 2011. Fishery and the use of space in a tropical semi-arid estuarine region of Northeast Brazil: subsistence and overexploitation. Journal of Coastal Research, vol. 64, p. 398-402.

GROTTA, M. and LUNETTA, JE., 1980. Ciclo sexual de Anomalocardia brasiliana (Gmelim, 1791) do litoral do estado da Paraíba. Revista Nordestina de Biologia, vol. 3, no. 1, p. $5-55$

GROTTA, M. and LUNETTA, JE., 1982. Influência dos fatores exógenos e endógenos sobre a reprodução de moluscos marinhos. Boletim Fisiologia Animal, vol. 6, p. 191-204.

HIROKI, K., 1971. Fisiologia de invertebrados marinhos, resistência a anoxia. Boletim de Zoologia e Biologia Marinha, vol. 28 , p. 315-341.

HIROKI, K., 1977. On the resistance of isolated bivalve gill pieces to oxygen deficiency and hydrogen sulphide. Boletim Fisiologia Animal, vol.1, p. 9-20.
LEONEL, RMV., MAGALHÃES, ARM. and LUNETTA, JE. 1983. Sobrevivência de Anomalocardia brasiliana (Gmelin,1791) (Mollusca: Bivalvia), em diferentes salinidades. Boletim de Fisiologia Animal, vol. 7, p. 63-72.

LUDWIG, JA. and REYNOLDS, JF., 1988. Statistical ecology: a primer on methods and computing. New York: John Wiley \& Sons. 337p.

MALIAO, RJ., WEBB, EL. and JENSEN, KR., 2004. A survey of stock of the donkey's ear abalone, Haliotis asinina L. in the Sagay Marine Reserve, Philippines: evaluating the effectiveness of marine protected area enforcement. Fisheries Research, vol. 66, p. 343-353.

MARTELL, KA., TUNNICLIFFE, V. and MACDONALD, IR., 2002. Biological features of a buccinid whelk (Gastropoda, Neogastropoda) at the endeavor vefefields of Juan de Fuça, northeast Pacific. Journal of Molluscan Studies, vol. 68, p. $45-53$.

MONTI, D., FRENKIEL, L. and MOUËZA, M., 1991. Demography and growth of Anomalocardia brasiliana (Gmelin) (Bivalvia, Veneridae) in a mangrove, in Guadeloupe (French West Indies). Journal of Molluscan Studies, vol. 57 , p. 249-257.

MOREIRA, ICN., 2007. Impactos do extrativismo de Anomalocardia brasiliana (Gmelin, 1791) nos estuários dos Rios Paciência e Cururuca, São Paulo, Maranhão: Uma visão etnoconservacionista. São Luis: Universidade Federal do Maranhão. 60 p. Dissertação de Mestrado em Biodiversidade e Conservação.

MORTON, B., BLACKMORE, G. and KWOK, CT., 2002. Corallivory and prey choice by Drupella rugosa (Gastropoda: Muricidae) in Hong Kong. Journal of Molluscan Studies, vol. 68, p. 217-223.

NARCHI, W., 1972. Comparative study of the functional morphology of Anomalocardia brasiliana (Gmelin, 1791) and Tivela mactroides (Born, 1778) (Bivalvia, Veneridae). Bulletin of Marine Science, vol. 22, p. 643-670.

NARCHI, W., 1974. Aspectos ecológicos e adaptativos de alguns bivalves do litoral paulista. Papéis Avulsos Zoologia, vol. 27, p. 235-262.

NARCHI, W., 1976. Ciclo anual da gametogênese de Anomalocardia brasiliana (Gmelin, 1791) (Mollusca: Bivalvia). Boletim Zoologia, vol. 1, p. 331-350.

NEUBERT, M. and CASWELL, H., 1997. Alternatives to resiliense for measuring the responses of ecological systems to perturbations. Ecology, vol. 78, no. 3, p. 653-665.

OLIVEIRA, IB., 2010. Estudo da estrutura populacional do marisco Anomalocardia brasiliana (Gmelin, 1791) na praia de mangue seco, litoral norte de PernambucoBrasil. Recife: Universidade Federal Rural de Pernambuco. 66 p. Dissertação de Mestrado em Recursos Pesqueiros e Aqüicultura.

PEDROSA, LFC. and COZZOLINO, SMF., 2001. Composição centesimal e de minerais de mariscos cruz e cozidos da cidade de Natal/RN. Ciência Tecnologia Alimentar, vol. 21, no. 2, p. 154-157.

PERILLO, GME., 1996. Geomorphology and sedimentology of estuaries. Amsterdam: Elsevier. $471 \mathrm{p}$.

PEZZUTO, PR. and ECHTERNACHT, AM., 1999. Avaliação de impactos da construção da Via Expressa SC-Sul sobre o berbigão Anomalocardia brasiliana (Gmelin, 1791) (Mollusca: Pelecypoda) na Reserva Extrativista Marinha do Pirajubaé (Florianópolis, SC - Brasil). Atlântica, vol. 21, p. 105-119.

PICKETT, STA. and WHITE, PS., 1985. The ecology of natural disturbance and patch dynamics. Orlando: Academic Press. 
PIMM, SL., 1984. The complexity and stability of ecossistem. Nature, v. 307, p. 321-326.

POLI, CR., POLI, ATB., ANDREATTA, E. and BELTRAME, EA. (Orgs.), 2004. Aquicultura: experiências Brasileiras. Florianópolis: Mutitarefa. 456p.

RIOS, EC., 1994. Coastal brazilian shells. Rio Grande: Fundação Cidade do Rio Grande. 255 p.

RICKLEFS, RE., 2010. A Economia da Natureza. Rio de Janeiro: Guanabara Koogan. 546p.

ROCHA-BARREIRA, CA., BATISTA, WF., MONTEIRO, DO. and FRANKLIN-JÚNIOR, W., 2002. Aspectos da estrutura populacional de Donax stratus (Linnaeus, 1758) (Molusca: Donacidae) na praia do futuro, Fortaleza/CE. Arquivos de ciências do mar, vol. 35, p. 51-55.

RODRIGUES, AML., 2009. Ecologia populacional do molusco bivalve Anomalocardia brasiliana (Gmelin, 1791) (Bivalvia) (Veneridae) em praias da região estuarina do Rio Apodi-Mossoró/RN. Mossoró: Universidade Federal Rural do Semi-Arido. 93p. Dissertação de Mestrado em Ciência Animal.
SCHAEFFER-NOVELLI, Y., 1980. Análise populacional de Anomalocardia brasiliana (Gmelin, 1791) (Mollusca: Bivalvia), na praia do Saco da Ribeira, Ubatuba, Estado de São Paulo. Boletim do Instituto de Oceanografia, vol. 29, no.2, p. 351-355.

SHEPARD, FP., 1954. Nomenclature based and sand-silt-clay ratios. Journal of Sedimentary Research, vol. 24, p. 151158.

SILVA, FC. and SILVEIRA JÚNIOR, N., 1992. Análise populacional de bivalves bentônicos de interesse econômico da Praia Comprida, Ilha de Santa Catarina - SC - Brasil (Relatório). Florianópolis: Universidade Federal de Santa Catarina.

SOARES, HA., SCHAEFFER-NOVELLI, Y. and MANDELLI-JÚNIOR, J., 1982. Berbigão A. brasiliana (Gmelin, 1791), bivalve comestível da região da Ilha do Cardoso, Estado de São Paulo/Brasil: Aspectos biológicos de interesse para a pesca comercial. Boletim do Instituto de Pesca, vol. 9, p. 21-38. 